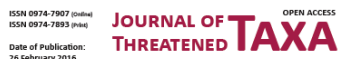

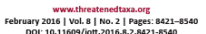
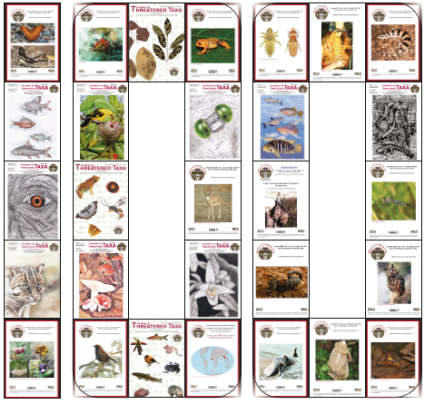

I S S UES

\section{Journal of Threatened Taxa}

The international journal of conservation and taxonomy

www.threatenedtaxa.org

ISSN 0974-7907 (Online) | ISSN 0974-7893 (Print)

SHORT COMMUNICATION

THREE INTERESTING WOOD ROTTING MACRO-FUNGI FROM

JHARKHAND, INDIA

Manoj Emanuel Hembrom, Arvind Parihar \& Kanad Das

26 February 2016 | Vol. 8 | No. 2 | Pp. 8518-8525

10.11609/jott.2133.8.2.8518-8525

For Focus, Scope, Aims, Policies and Guidelines visit http://threatenedtaxa.org/About_JoTT.asp For Article Submission Guidelines visit http://threatenedtaxa.org/Submission_Guidelines.asp For Policies against Scientific Misconduct visit http://threatenedtaxa.org/JoTT_Policy_against_Scientific_Misconduct.asp For reprints contact <info@threatenedtaxa.org> 


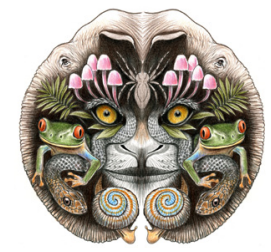

ISSN 0974-7907 (Online) ISSN 0974-7893 (Print)

\section{OPEN ACCESS}

\title{
THREE INTERESTING WOOD ROTTING MACRO-FUNGI FROM JHARKHAND, INDIA
}

\author{
Manoj Emanuel Hembrom ${ }^{1}$, Arvind Parihar ${ }^{2}$ \& Kanad Das ${ }^{3}$ \\ ${ }^{1}$ Central National Herbarium, ${ }^{2,3}$ Cryptogamic Unit, \\ Botanical Survey of India, P.O. B. Garden, Howrah, West Bengal 711103, India \\ ${ }^{1}$ manojhembrom@yahoo.co.in (corresponding author), ${ }^{2}$ arvind_peace@rediffmail.com, ${ }^{3}$ daskanadbsi@gmail.com
}

Abstract: Routine surveys of mycologically unexplored forest areas of Jharkhand, followed by a thorough examination of macrofungal collections reveal two hitherto unrecorded poroid species (Basidiomycete) for Indian mycobiota namely, Ganoderma elegantum and Perenniporia bambusicola, and a less known hydnoid woodrotting species Beenakia fuliginosa. Detailed taxonomic descriptions coupled with illustrations are provided for all three taxa and compared with allied taxa.

Keywords: India, Jharkhand, Wood-rotting macrofungi.

Jharkhand is one of the richest states of India in terms of forest and mineral resourses. Forests are mainly dominated by many economically important plants including sal (Shorea robusta) and bamboos, which are major sources of forest products for the native tribal people as well as being a rich host of wood rotting macrofungi. Rajmahal Hills and Koderma Wildlife Sanctuary are parts of this state and remain neglected from the mycological point of view except for a few sporadic reports (Currey 1874; Bodding 1925-1940; Panigrahi 1966; Anonymous 2013; Parihar et al. 2013). A critical examination of the specimens and a study of the relevant literature (Sorbhoy et al. 1981; Bilgrami et al. 1991; Jamaluddin et al. 2004; Ranadive et al. 2011; Sharma 2012; Tiwari et al. 2013) revealed two new records and one less known to Indian mycobiota and are presented here with descriptions and illustrations of macro- and micro-morphological details.

\section{MATERIALS AND METHOdS}

Macro-fungal surveys of tropical deciduous (50-450 $\mathrm{m}$ ) forest areas have been undertaken during the monsoon (August-September) season from 2008 to 2014. Macromorphological characterization was made with the fresh basidiomata in the field or in the base camp (Fig. 1). Field photographs of these fresh macro-fungi and their habitats were captured with the aid of a Nikon D200s and Olympus C-5060. Colour codes and terms (mostly) are based on the Methuen Handbook of Colour (Kornerup \& Wanscher 1978). After the Macromorphological characterization basidiomata were dried with the help of a wooden drier.

Micromorphological characterization was undertaken with the help of a light microscope: Olympus CX 41 from the free hand sections of the dry basidiomata mounted in a mixture of $5 \% \mathrm{KOH}$, phloxin, Congo red, and separately with Melzer's reagent or lacto-phenol and cotton blue. Measurements of spores were noted from 20 randomly chosen basidiospores. Spore-measurement and quotient indicating length-width ratio $(\mathrm{Q}=\mathrm{L} / \mathrm{W})$ are presented here as minimum-mean-maximum. Herbarium name follows

DOI: http://dx.doi.org/10.11609/jott.2133.8.2.8518-8525

Editor: R.K. Verma, Tropical Forest Research Institute, Jabalpur, India.

Date of publication: 26 February 2016 (online \& print)

Manuscript details: Ms \# 2133 | Received 30 June 2015 | Final received 23 August 2015 | Finally accepted 02 February 2016

Citation: Hembrom, M.E., A. Parihar \& K. Das (2016). Three interesting wood rotting macro-fungi from Jharkhand, India. Journal of Threatened Taxa 8(2): 8518-8525; http://dx.doi.org/10.11609/jott.2133.8.2.8518-8525

Copyright: () Hembrom et al. 2016. Creative Commons Attribution 4.0 International License. JoTT allows unrestricted use of this article in any medium, reproduction and distribution by providing adequate credit to the authors and the source of publication.

Funding: Botanical Survey of India, Ministry of Environment, Forest and Climate change, Govt. of India.

Conflict of Interest: The authors declare no competing interests.

Acknowledgments: The authors are grateful to the Director, Botanical Survey of India (BSI), Kolkata and the entire forest department of Jharkhand for providing all kinds of facilities during the present study. Help rendered by Dr. Md. N. Aziz (BSI, Cryptogamic Unit) and Dr. P. Lakshminarasimhan (BSI, Central National Herbarium) are also duly acknowledged. 


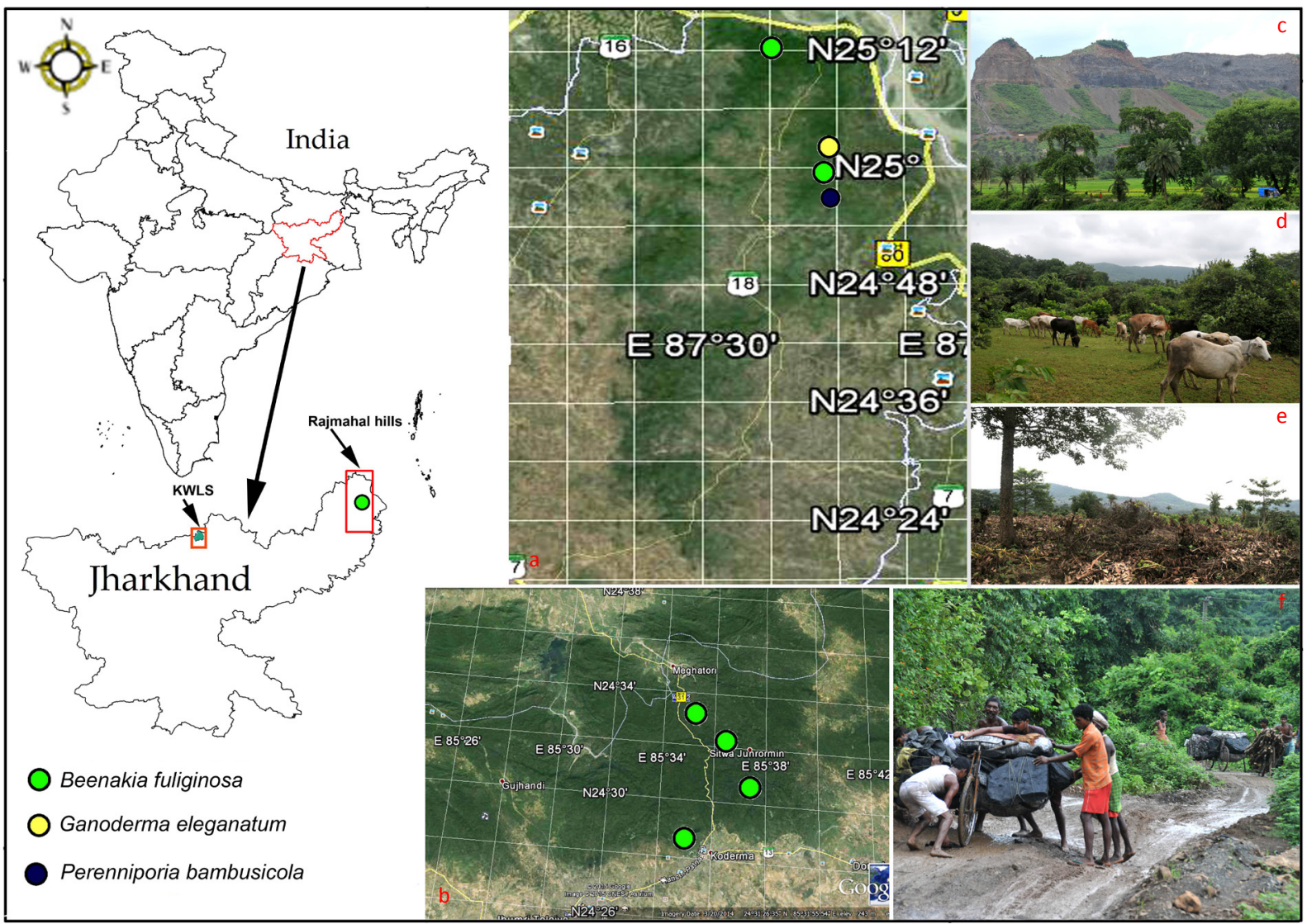

Figure 1. a - Google image of Rajmahal hills showing distribution of Beenakia fuliginosa, Ganoderma elegnatum and Perenniporia bambusicola; b - Google image of Koderma Wildlife Sanctuary showing distribution of Beenakia fuliginosa; $c-f$ - Anthropogenic activities in the Rajmahal Hills causing habitat loss

Holmgren et al. (1990).

\section{Taxonomic enumeration \\ Clavariadelphaceae}

Beenakia fuliginosa (Mass Geest.) Parmasto \& Ryvarden, Windahlia 18: 39, 1990. (Image 1 \& Fig. 2)

Basidomata annual, 80-160 × 65-210 mm, substipitate to dimidiate, fused at base giving imbricate appearance. Pilear surface hispid to scrobiculate, small hairs agglutinated to form pyramidal shape, glabrous and smooth when dried, weakly zonate to azonate, concentrically sulcate, grayish-yellow (4B5-4B6). Margin sterile, obtuse, chalky white (A1) to pale red (10A3) or dull red (10B3) to mostly separated zones of dark green (28F8). Stipe very short, tapered at base to $50 \mathrm{~mm}$ long and 5-15 $\mathrm{mm}$ wide, covered with spines, chalky white when fresh, dark ochraceous when dried. Hymenophore hydnoid, crowded with spines, chalky white to pale orange (5A3) to greyish orange (5B3) when fresh; spines 1-2 per $\mathrm{mm}, 2-10 \mathrm{~mm}$ long cylindrical, acute at tip; white mycelial mat spread throughout. Context 3-10 mm thick at base and gradually thinning towards the margin, soft and spongy, dark fuscous zone, chalky white when fresh, pale ochraceous when dried.

Hyphal system monomitic. Generative hyphae thinto thick-walled, branched, septate and clamped, a few flattened hyaline. Contextual hyphae 4-9 $\mu \mathrm{m}$ wide, thinwalled, smooth, highly interwoven. Subicular hyphae 2.5$6 \mu \mathrm{m}$ wide, thick-walled, heavily granulate. Basidioles 15.5-23 × 5-6 $\mathrm{mm}$, clavate, clamped at base, partially granulate. Basidia 14-26 × 5-7 $\mu \mathrm{m}$, cylindrical to clavate, clamped at base, 4-sterigmate (sterigmata 2.5-6.3 $\mu \mathrm{m}$ ). Basidiospores 5-6.55-8 × 4-4.52-5 $\mu \mathrm{m}$, with $\mathrm{Q}=1.2-$ 1.45-2, pip shaped, verruculose, obliquely apiculate, adaxially flattened, one to three guttulate, hyaline to weakly cyanophilous and inamyloid.

Specimens examined: MEH-13-53 (CAL), 22.viii.2013, India, Jharkhand, Rajmahal Hills, Sahibganj District,

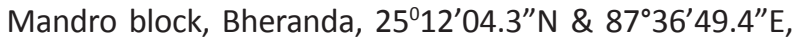
$184 \mathrm{~m}$ elevation, on living Morus alba trunk near base, coll. M.E. Hembrom; MEH-13-148 (CAL), 31.viii.2013, Taljhari

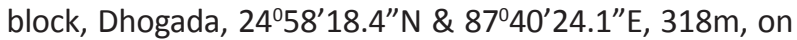
living cut stump of Shorea robusta, coll. M.E. Hembrom; 44905 (CAL), 03.ix.2010, Koderma Wildlife Sanctuary, 
Mughalamaran, 24030'59.70"N \& 85034'29.40" $\mathrm{E}$, $392 \mathrm{~m}$, on living angiosperm shrub, coll. Arvind Parihar; 44930 (CAL), 06.ix.2010, Basraun, 24³3'48.90”N \& $85^{\circ} 37^{\prime} 44.80^{\prime \prime} \mathrm{E}, 372 \mathrm{~m}$, on living angiosperm shrub, Arvind Parihar; 44989 (CAL), 16.ix.2010, Koderma enclosure, $24^{\circ} 29^{\prime} 18.70^{\prime \prime} \mathrm{N} \& 85^{\circ} 35^{\prime} 50.10^{\prime \prime} \mathrm{E}, 388 \mathrm{~m}$, on the base of a living angiosperm tree, coll. Arvind Parihar; 45027 (CAL), 45028 (CAL), 13.x.2011, Koderma NRF, 24²9'06.60” N \& $85^{\circ} 35^{\prime} 49.80^{\prime \prime} \mathrm{E}, 394 \mathrm{~m}$, on the base of a living angiosperm tree, coll. Arvind Parihar; 45099 (CAL), 19.x.2011, Chatarbar, $379 \mathrm{~m}, 24^{\circ} 28^{\prime} 01.90^{\prime \prime} \mathrm{N} \& 85^{\circ} 32^{\prime} 13.10^{\prime \prime} \mathrm{E}$, on the base of a living angiosperm shrub, Arvind Parihar; 6646

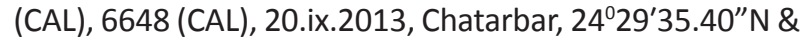
$85^{\circ} 36^{\prime} 13.50^{\prime \prime} \mathrm{E}, 388 \mathrm{~m}$, on the base of a living angiosperm shrub, coll. Arvind Parihar; 6668 (CAL), 24.ix.2013, Khalakhtambhi, $24^{\circ} 28^{\prime} 24.10^{\prime \prime} \mathrm{N} \& 8^{\circ} 32^{\prime} 28.50^{\prime \prime} \mathrm{E}, 378 \mathrm{~m}$, on the base of a living angiosperm shrub, coll. Arvind Parihar.

Distribution: Zambia; India, Tamil Nadu and Jharkhand (Rajmahal Hills \& Koderma Wildlife Sanctuary).

Notes: Genus Beenakia includes those hydnoid macro-fungi which bear macromorphological features like pileate, stipitate basidiomata with rounded, spinose hymenophore and micro-morphological features like septate clamped smooth to warted generative hyphae; clamped basidia and ellipsoid to pip-shaped or almost navicular ornamented, hyaline to yellowish, inamyloid basidiospores (Reid 1955 ; Cunningham 1958; Mass MassGeesteranus 1971; Parmasto \& Ryvarden 1990; Nunez \& Ryvarden 1994). In the family Clavariadelphaceae this genus presently holds seven valid species including Beenakia fuliginosa worldwide (www.index fungorum. org). The present species was erected by MassGeesteranus (1977) as Psathyrodon fuligionsus on the basis of basidiomata and spore colour, but after a critical study of type materials including Indian collections as well as re-collected materials from type locality on same substrate, it appears that these features are insufficient to raise $B$. fuliginosa as under new status by placing as $P$. fuliginosus. Hence $P$. fuliginosus becomes a synonym of $B$. fuliginosa (Parmasto \& Ryvarden 1990).

This is an undocumented species in the regional and national mycoflora of India and so far only collected once from Tamil Nadu by Parmasto in 1979 (Parmasto \& Ryvarden 1990). Its habitat is also interesting because it grows on the base of living stumps of Shorea robusta (as observed from present study); however, a few specimens were also found to grow on Morus alba L. and other trees and shrubs from the study areas.

Macro- and micro-morphologically, the present specimens are fairly within the circumscriptions provided

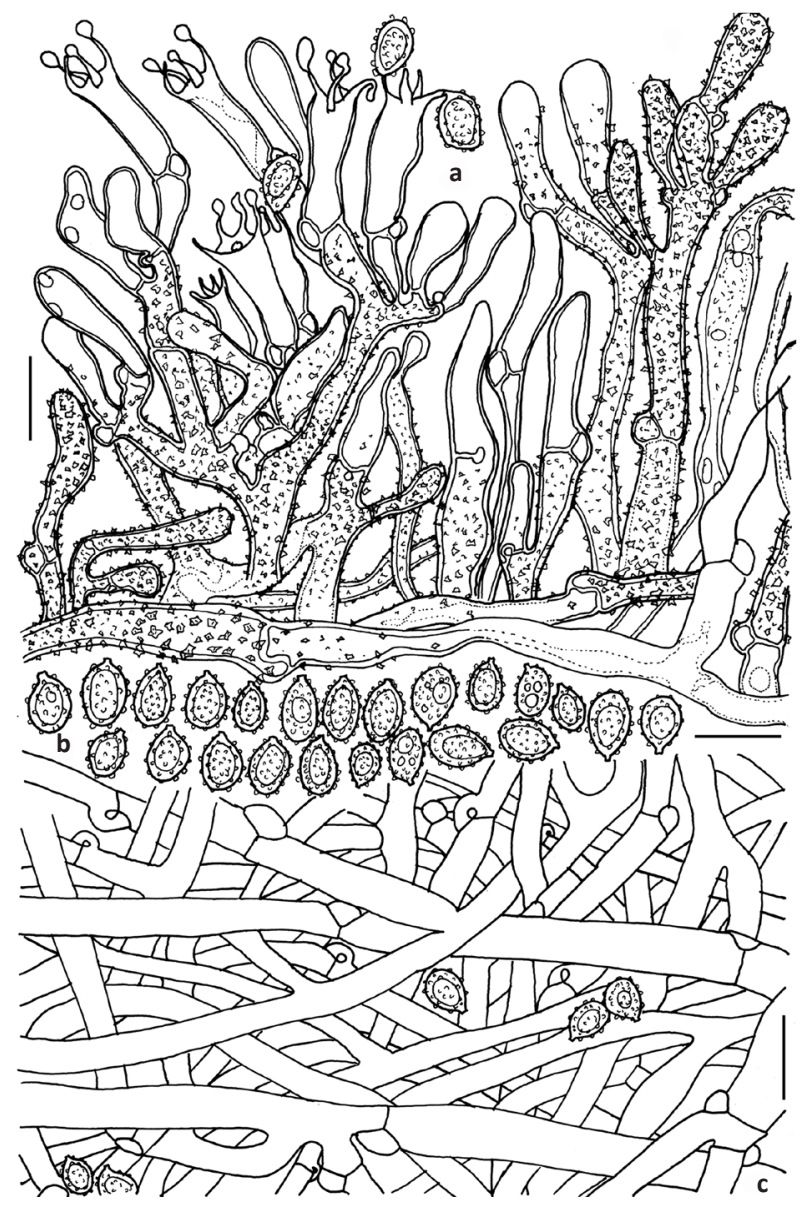

Figure 2. Beenakia fuliginosa. a - section through the hymenium showing basidia; basidioles, basidiospores and incrustation on subicular hyphae; b - basidiospores; c - interwoven hyphae in context; Scale bars: $a-c=10 \mu \mathrm{m}$

by Parmasto \& Ryvarden (1990) and Nunez \& Ryvarden (1994) supported by the illustration of Mass-Geesteranus (1977); except the color of basidiomata (Pink), which may be due to geographical variation. Significant taxonomic features like monomitic clamped generative hyphae, which are thick-walled and granular insubiculum and pip shaped, verruculose, obliquely apiculate, adaxially flattened basidiospores associated with present specimens strongly recommends placing them as $B$. fuliginosa. Moreover, supplementary features of basidiospores as revealed from scanning electron microscopic (SEM) studies also agreed with that of Julich \& Star (1983), and Parmasto \& Ryvarden (1990).

\section{Ganodermataceae}

Ganoderma elegantum Ryvarden, Syn. Fung. (Oslo) 19: 81 (2004). (Image 2 \& Fig. 3)

Basidiomata 40-58 $\mathrm{mm}$ high, annual, humicolous (perhaps attached to buried roots of bamboos), laterally 

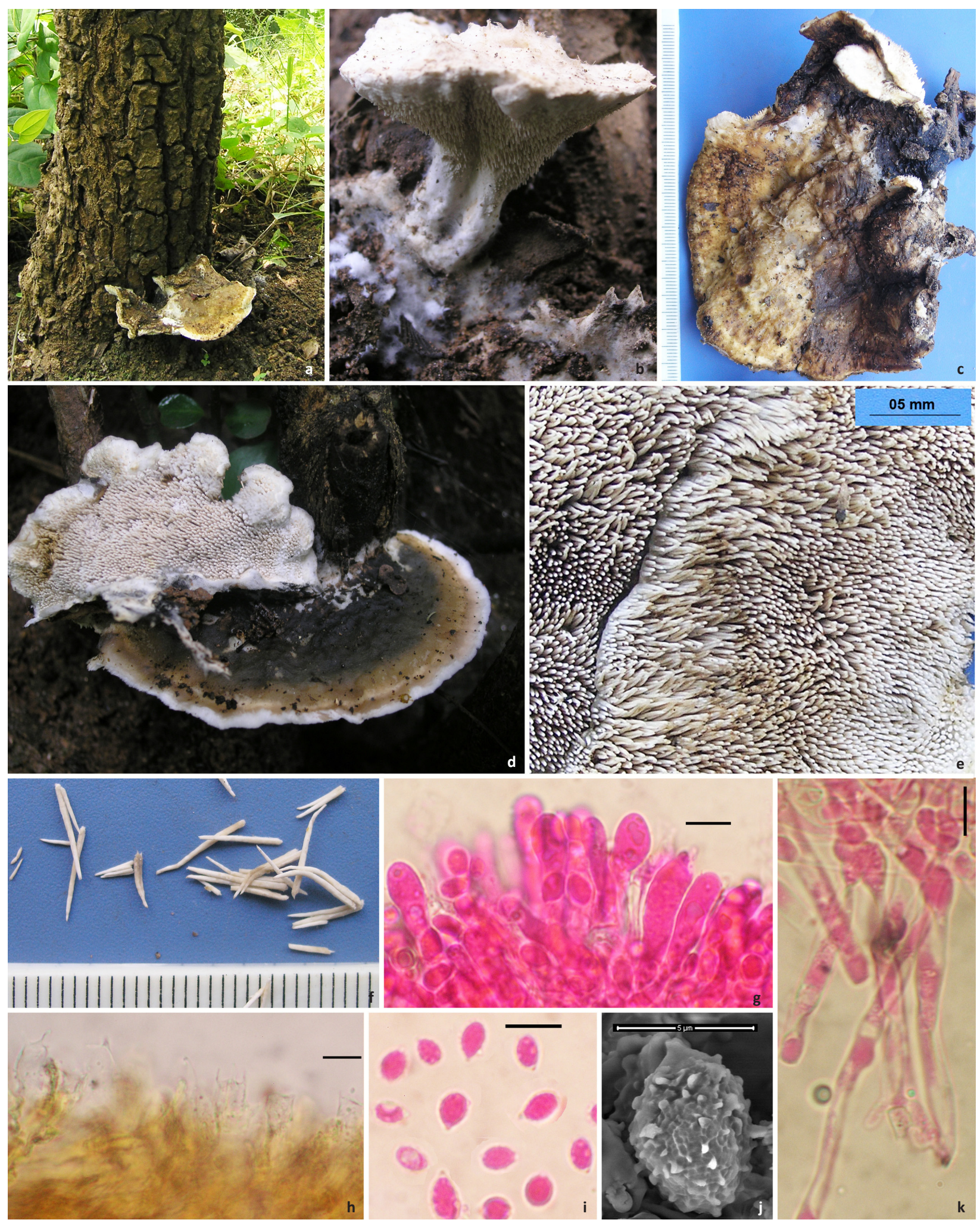

Image 1. Beenakia fuliginosa. a - habitat; $\mathrm{b}$ - stipitate habit of basidiomata; c- basidiomata showing pilear surface with scale.; $\mathrm{d}$ - basidiomata showing pilear surface and pore surface; $\mathrm{e}$ - hydnoid hymenophore; $\mathrm{f}$ - teeth with scale; $\mathrm{g}$ - basidioles and basidiospores; $\mathrm{h}$ - basidia;

-I - basidiospores; j - SEM image of basidiospores; $\mathrm{k}$ - hyphal ends from teeth; scale bars: $\mathrm{e}=5 \mathrm{~mm} ; \mathrm{g}-\mathrm{i} \& \mathrm{k}=10 \mu \mathrm{m} ; \mathrm{j}=5 \mu \mathrm{m}$. @ Arvind Parihar 
stipitate, light weight. Pileus $15-20 \times 12-17 \mathrm{~mm}$ and 8-10 $\mathrm{mm}$ thick near the stipe; surface indistinctly zonate in the middle while more distinct and sulcate towards the margin, glabrous, laccate, dark brown (7F6-7F7). Margin up to $0.5 \mathrm{~mm}$ wide, obtuse, distinct to indistinct from hymenial surface, sterile, concolourous with hymenophore. Pore surface pale yellow (4A3) to pale orange (5A3); pores 5-7 per $\mathrm{mm}$, angular to rounded, white when fresh and ochraceous white at maturity. Stipe $40-45 \mathrm{~mm}$ long and 4-5 mm in diameter, cylindrical, bottleneck like near base, ring like zones in the stipe, laccate, glabrous, sulcate, and concolourous with pilear surface. Pilear context 1-5 mm thick, distinctly duplex, two black dense bands originating at the bottom of the stipe extended up to the pileus, upper part brown (6E5) and lower part dark brown (6F5); stipe context distinctly zonate, outer layer light brown, 1-2 $\mathrm{mm}$ thick and inner layer 2-3 $\mathrm{mm}$ thick, dark brown. Tubes 1-3 mm long, straight, paler than context.

Cuticle layer 20-50 $\mu \mathrm{m}$ thick, yellowish brown; cuticular cells $17-42 \times 8-12 \mu \mathrm{m}$, thick-walled to solid, apically widened with a narrow lower part, smooth, apically amyloid. Hyphal system dimitic; generative hyphae 2.5-5 $\mu \mathrm{m}$ wide, thin-walled, clamped, branched, rare, smooth, hyaline. Skeletal hyphae 2.5-9 $\mu \mathrm{m}$ wide, thick-walled, wall 1-3 $\mu \mathrm{m}$ thick, abundant, arboriform, smooth, hyaline to yellowish-brown. Basidia and basidioles not found. Basidiospores 8-9.7-12 × 5.5-6.3-7.5 $\mu \mathrm{m}$, $\mathrm{Q}=1.33-1.51-1.8$, oblong ellipsoid, truncate or rounded at the apex, acyanophilic, inamyloid; exospores smooth and hyaline; endospore ornamented, brown.

Specimens examined: MEH-13-087 (CAL), 26.viii.2013, India, Jharkhand, Rajmahal Hills, Sahibganj District, Borioblock, Dalabari Village, $25^{\circ} 02^{\prime} 34.8^{\prime \prime} \mathrm{N} \& 8^{\circ} 39^{\prime} 55.3^{\prime \prime} \mathrm{E}$, $106 \mathrm{~m}$, on soil probably attached to buried bamboos root, near dead bamboo thickets, coll. M.E. Hembrom.

Distribution: Ecuador; India (Jharkhand, Rajmahal hills).

Notes: So far this species has been reported only from its type locality (Amazonas jungle in Ecuador confined to the neo-tropical belt) as mentioned by Ryvarden (2004) and this is the second collection from the paleo-tropical belt indicating its rare but wide range of distribution. Though the present description is based on two basidiomata collected from the Rajmahal Hills, Jharkhand, it holds enough macro- and micro-morphological features like long slender stipe, black melanoid bands in the pale brown context and oblong spores (Ryvarden 2004) to recognize the present collection as Ganoderma elegantum. The present specimens slightly differ as compared to type, in having apically rounded as well as truncate basidiospores ('apically rounded' in the protolouge). The stipe is shorter

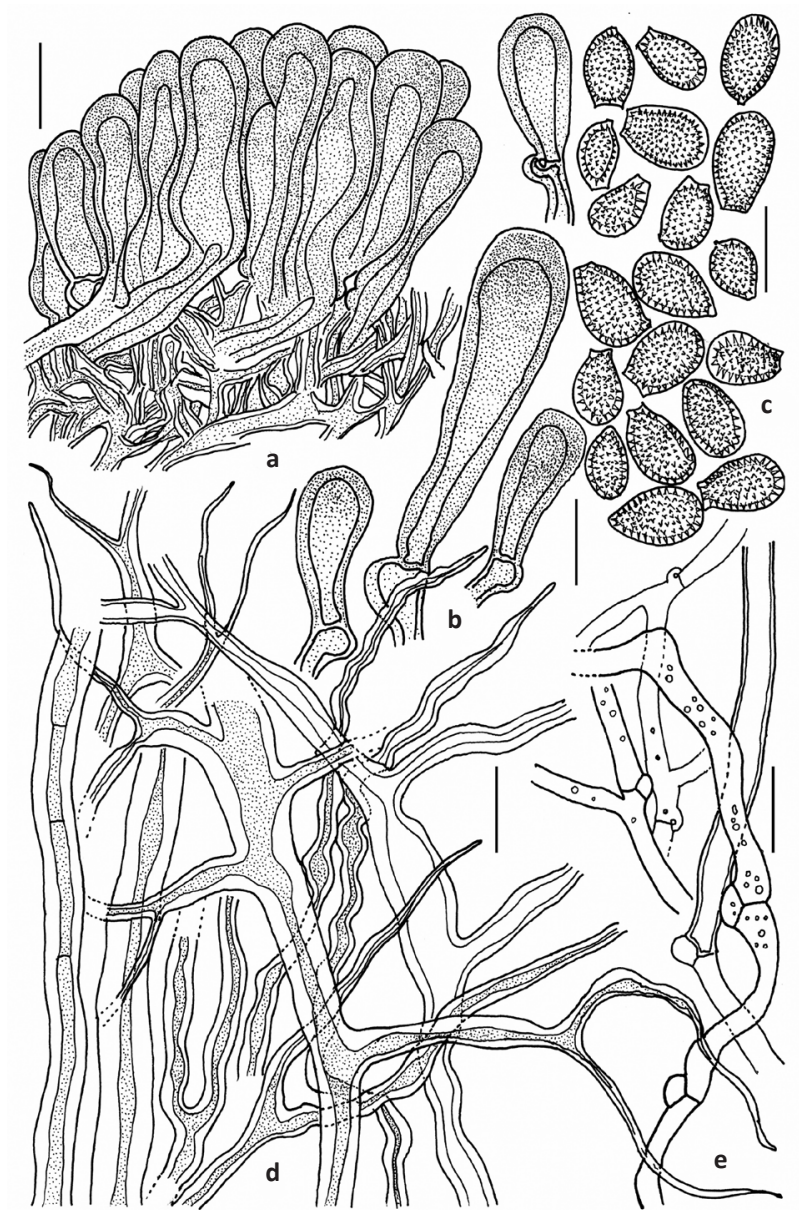

Figure 3. Ganoderma elgantum. a - cuticular cells; b - cuticular cells showing clamp at base; c - basidiospores; d - skeletal hyphae; e clamped generative hyphae; Scale bars: $\mathrm{a}-\mathrm{e}=10 \mu \mathrm{m}$

as compared to the type material (stipe is up to $150 \mathrm{~mm}$ long). Another taxon G. stipitatum Murill appeared to be allied due to a combination of characters like amyloid cuticular cells, duplex context separated by melanoid band (as Ryvarden 2004) but its short to almost negligible stipe, more club like and evenly widened cuticular cells and small basidiospores as compared to the present taxon $(8-12 \times 5.5-7.5 \mu \mathrm{m})$ separate it from the previous one. Tiwari et al. (2013) reported 17 species of Ganoderma from central India, but it excludes the present species.

\section{Polyporaceae}

Perenniporia bambusicola Choeyklin, T. Hatt. \& E.B.G. Jones, Fungal Diversity 36: 122 (2009) (Image 3 \& Fig. 4)

Basidiomata 3-55 $\times 2-25 \mathrm{~mm}$ and up to $0.5-1 \mathrm{~mm}$ thick, annual, resupinate, effused, corky when dried. Hymenophoreporoid to decurrent; pores 4-7 per mm, angular to round, deep orange (5A7) to light orange $(5 A 5-5 A 4)$ when fresh and light orange (5A4) when 


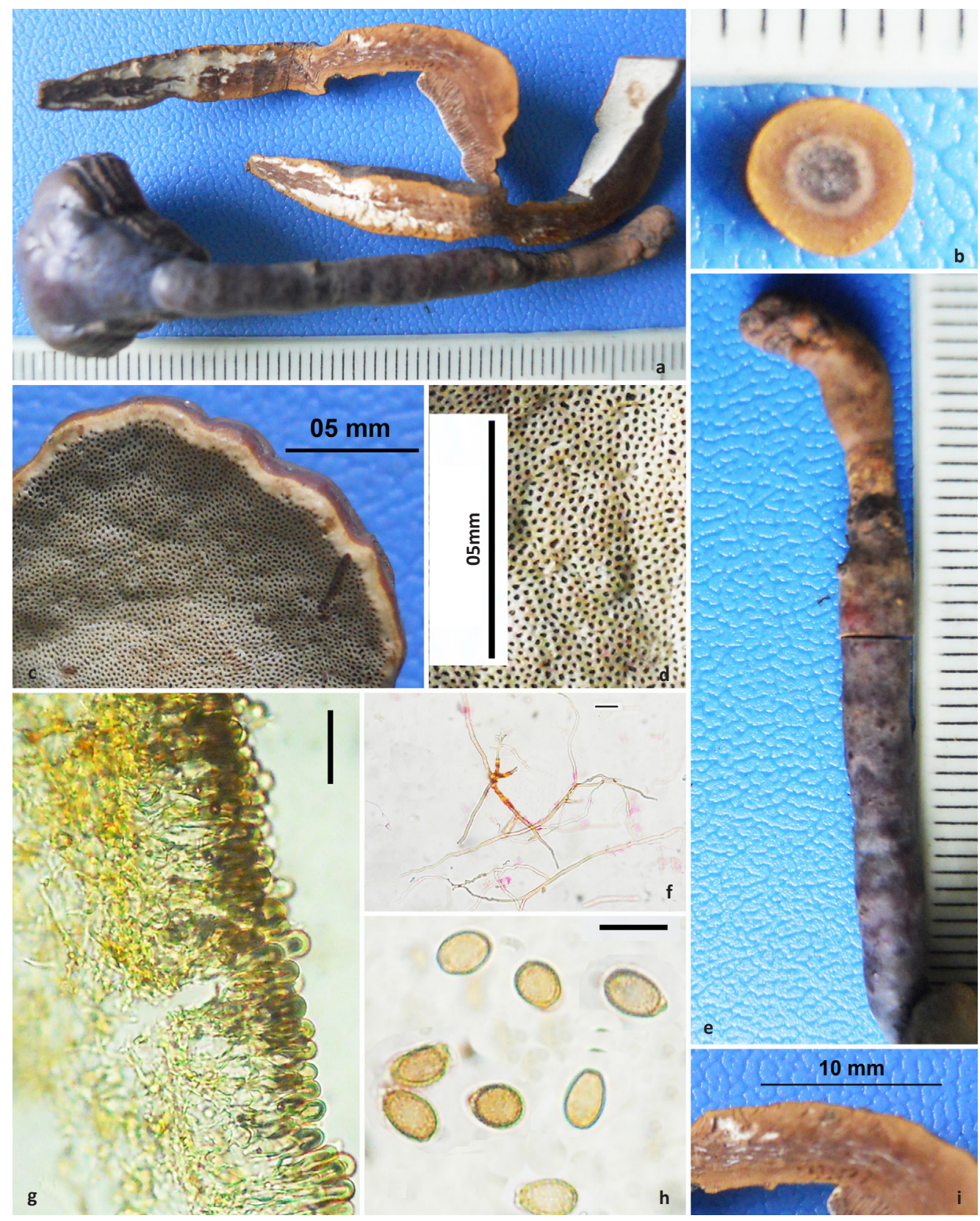

Image 2. Ganoderma elgantum. a - stipitate basidiomata with scale; b - section of stipe showing duplex context; c - basidiomata showing pore surface; $d$ - pores with scale; e - stipe; $f$ - arboriform skeletal hyphae; $g$ - section showing cuticular cells; $h$ - basidiospores; $i$ - context. Scale bars: $d=5 \mathrm{~mm} ; f=50 \mu \mathrm{m} ; g \& h=10 \mu \mathrm{m} ; i=10 \mathrm{~mm}$. (C) M.E. Hembrom

dried; dissepiments thin and entire; violet to black with $\mathrm{KOH}$. Margin indistinct, white mycelium present near periphery but disappear when dried. Subiculum very thin ochraceous to pale orange. Tubes tough-fibrous to leathery, decurrent, concolorous with hymenophore.

Hyphal system dimitic. Generative hyphae 1.5-3.5 $\mu \mathrm{m}$ wide, thin-walled, smooth, clamped, occasionally branched, infrequent in subiculum and tubes, hyaline. Skeletal hyphae 2.5-5 $\mu \mathrm{m}$ wide, thick-walled, wall up to $1 \mu \mathrm{m}$ thick, arboriform with stalk and side branches, dominating in subiculum and tubes, interwoven but more or less parallel near substrate, crystalline particles present changing into violet colour with $10 \% \mathrm{KOH}$, hyaline to more or less dextrinoid when agglutinated. Fusoid cystidioles 16-27 × 3.5-5 $\mu \mathrm{m}$, thin-walled, smooth, hyaline. Basidioles 12-13 × 5.5-7.5 $\mu \mathrm{m}$, clamped at base, smooth, hyaline. Basidia 12-16 × 5-7 $\mu \mathrm{m}, 4$-sterigmate, sterigmata 3-5 $\mu \mathrm{m}$ long, clamped at base, smooth, hyaline. Basidiospores 3.5-4.87-6 × 2.5-3.28-4 $\mu \mathrm{m}, \mathrm{Q}$ = 1.21-1.49-2, oblong ellipsoid, truncate, thick-walled, 


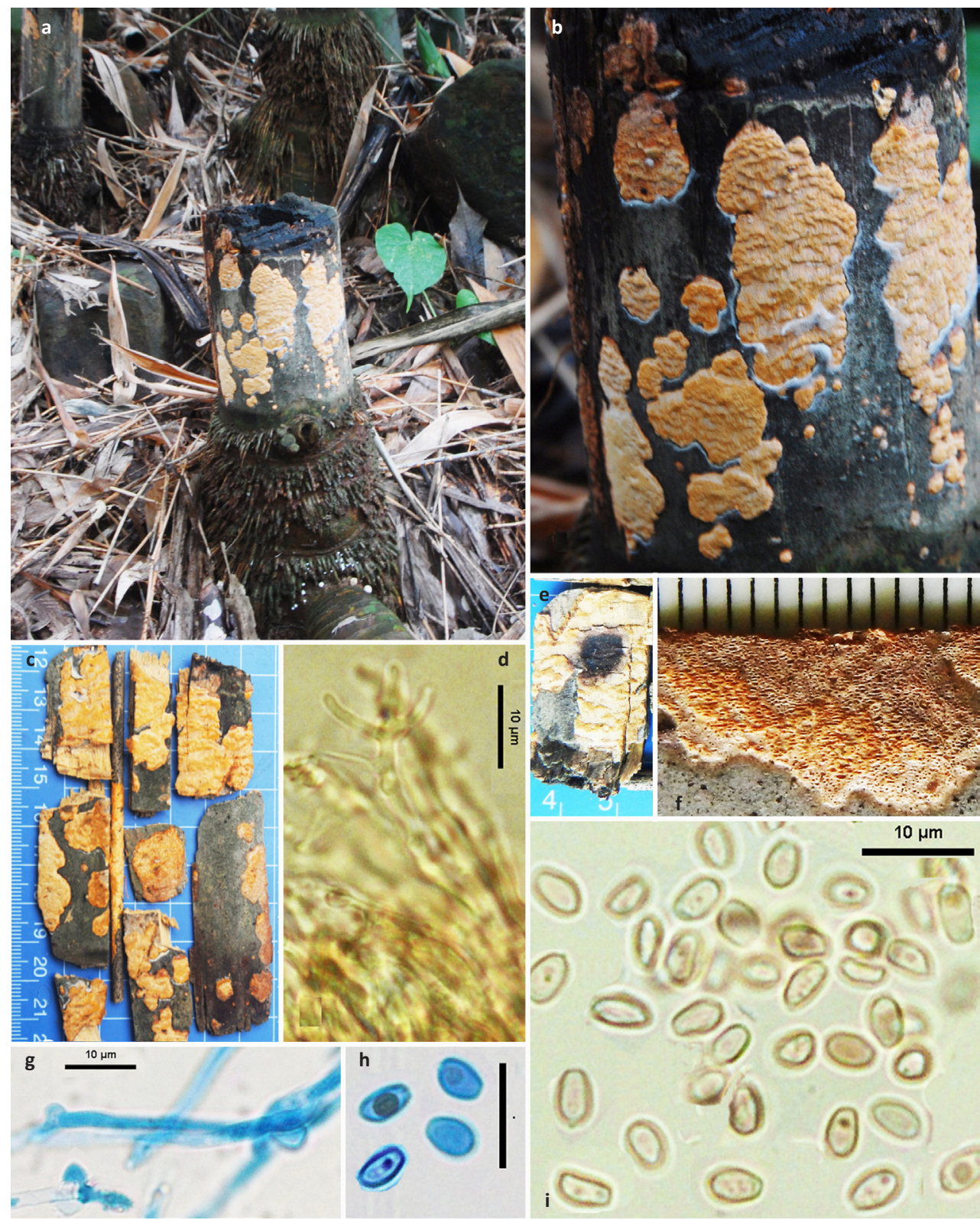

Image 3. Perenniporia bambusicola. a - habitat; b - resupinate habit of basidiomata; c - basidiomata with scale; $\mathrm{d}$ - skeletal hyphae from the hymenium; e - basidiomata turning black with $\mathrm{KOH} ; \mathrm{f}$ - poroid hymenophore; $\mathrm{g}$ - clamped generative hyphae; $\mathrm{h}$ - basidiospores showing cyanophilic reaction; $i$ - weakly dextrinoid basidiospores; Scale bars: $d=10 \mu \mathrm{m} ; \mathrm{g}-\mathrm{i}=10 \mu \mathrm{m}$. C M.E. Hembrom

smooth, hyaline, cyanophilic, weakly dextrinoid.

Specimens examined: MEH-66240 (CAL), 26.viii.2014, India, Jharkhand, Rajmahal Hills, Sahibganj District, Taljhari block, Paderkola Village Dhamdhamia, 60m, $24^{\circ} 55^{\prime} 57.0^{\prime \prime} \mathrm{N} \& 87^{\circ} 45^{\prime} 09.1^{\prime \prime} \mathrm{E}$, on dead bamboo-roots and fallen leaf litter of bamboos, coll. M.E. Hembrom.

Distribution: Thailand, China and India (Jharkhand, Rajmahal Hills).

Notes: Whereas the species' epithet itself indicates the present taxon's habitat (confined to bamboos exclusively), the habit shows (resupinate orange hymenophore which turns into violet black with $\mathrm{KOH}$ ) very characteristic and separating features from its close allies Perenniporia corticola (Corner) Decock and P. xantha Decock \& Ryvarden. Perenniporia xantha can be demarked with the help of bright yellow hymenophore, arboriform skeletal hyphae and host asangiospermic wood (Decok \& Ryvarden 1999; Zhao \& Cui 2012) (never on bamboos). Its macro and microscopic characters are fairly within the range of type (Choeyklin et al. 2009) supported by the circumscription of Zhao \& Cui (2012) except, its basidiospores, which are slightly larger than that of Zhao 


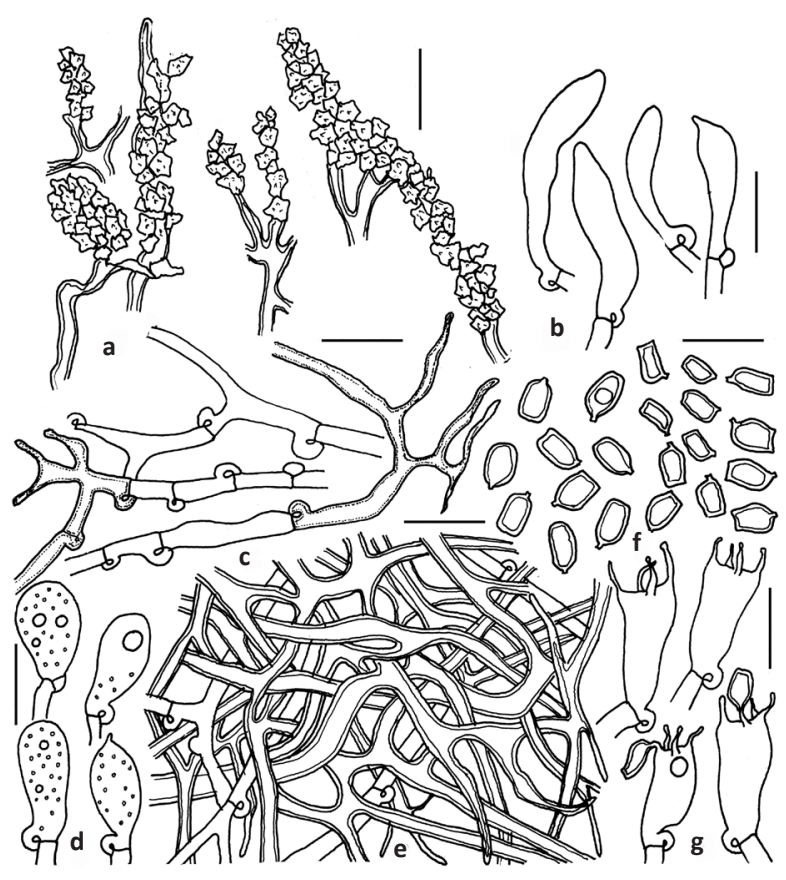

Figure 4. Perenniporia bambusicola. a - skeletal hyphae with crystalline particles; $\mathbf{b}$ - fusoid cystidioles; $\mathrm{c}$ - clamped generative hyphae; $\mathrm{d}$ - basidioles; e - interwoven hyphae in the trama; $f$-basidiospores; $g$ - basidia. Scale bars: $\mathrm{a}-\mathrm{g}=10 \mu \mathrm{m}$

\& Cui $(2012 ; 4-5.3 \times 2.5-4 \mu \mathrm{m})$ but well agreeable with protolouge $(3.5-5.8 \times 2.2-3.9 \mu \mathrm{m}$ as Choeyklin et al. 2009) to determine it as $P$. bambusicola.

\section{Discussion}

Along with a large number of other fleshy fungi, the wood-rotting macrofungi face a serious threat from the high anthropogenic pressure causing habitat loss day by day due to mining, road construction, overgrazing, jhoomcultivation and forest fires (Fig. 1). Species by species approach (for conservation) is not the realistic way in a poor country like India. Therefore, it is an exigency of conserving the habitats as such in a sustainable manner because livelihoods of the Santhal and Paharia tribes depend upon the forest (Rajmahal Hills) resources of these areas (Fig. 1). This approach will not only protect the species in discussion but also the large mycobiota of these areas will be conserved. So far no assessments have been done for wood-rotting mycobiota of these regions as per the recent IUCN categories of their occurrences, and hence more extensive surveys and ecological studies are needed to conserve the wood rotting fungi in the near future.

\section{REFERENCES}

Anonymous (2013). Annual Report Botanical Survey of India, 32pp.

Bilgrami, K.S., S. Jamaluddin \& M.A. Rizwi (1991). Fungi of India List and References. Today and Tomorrows Printers \& Publishers, New Delhi, 798pp.

Bodding, P.O. (1925-1940). Studies in Santal medicine and connected folklore. Parts I, II \& III. The Asiatic Society, Calcutta, 502pp.

Cunningham, G.H. (1958). Hydnaceae of New Zealand. Part I. The pileate genera Beenakia, Dentipellis, Hericium, Hydnum, Phellodon and Steccherinum. Transactions of the Royal Society of New Zealand 85: 585-601.

Choeyklin, R., T. Hattori, S. Jaritkhuan \& E.B.G. Jones (2009). Bambusicolous polypores collected in Central Thailand. Fungal Diversity 36: 121-128.

Currey, F. (1874). On a collection of fungi made by Mr. SulpizKurz, Curator of the Botanic Garden, Calcutta. Transaction of the Linnaean Scoiety London, II, Series. Bot. I, 119-131pp.

Decock, C. \& L. Ryvarden (1999). Studies in neotropical polypores. Some colored resupinate Perenniporia species. Mycological Research 103: 1138-1144.

Holmgren, P.K., N.H. Holmgren \& L.C. Barnett (1990). Index Herbariorum. Part I: The Herbaria of the World [Regnum Veg. vol. 120]. New York Botanical Garden, New York.

Jamaluddin, S., M.G. Goswami \& B.M. Ojha (2004). Fungi of India 1989-2001. Scientific Publishers (India), Jodhpur, India.

Julich, W. \& W. Star (1983). Ultra structures of basidiospores, 1. Beenakia. Persoonia 12: 67-74.

Kornerup, A. \& J.H. Wanscher (1978). Methuen Handbook of Colour. $3^{\text {rd }}$ Edition. Eyre Methuen Ltd. Reprint, London, UK, 252pp.

Mass-Geesteranus, R.A. (1971). Hydnaceous fungi of Eastern old world. Proceedings of the Koninklijke Nederlandse Akademie Van Wetenschappen Series 2, part 60, no. 3: 1-175.

Mass-Geesteranus, R.A. (1977). Psathyrodon, a new hydnaceous genus. Kew Bulletin 31(3): 417-419.

Nunez, M. \& L. Ryvarden (1994). A note on the genus Beenakia. Sydowia 46(2): 321-328.

Panigrahi, G. (1966). A Botanical Tour in the Rajmahal Hills of Bihar. Bulletin of the Botanical Survey of India 8(1): 1-15.

Parihar A., M.E. Hembrom \& K. Das (2013). New distributional records of Ganoderma colossus (Ganodermataceae) from Jharkhand and Rajasthan. Indian Journal of Plant Sciences 2(4): 49-53.

Parmasto, E. \& L. Ryvarden (1990). The genus Beenakia (Gomphaceae, Aphyllophorales). Windahlia 18: 35-42.

Ranadive, K.R., J.G. Vaidya, P.K. Jite, V.D. Ranade, S.R. Bhosale, A.S. Rabba, M. Hakimi, G.S.Deshpande, M.M. Rathod, A. Forutan, M. Kaur, C.D. Naik-Vaidya, G.S. Bapat \& P. Lamrood (2011). Checklist of Aphyllophorales from the Western Ghats of Maharashtra State, India. Mycosphere 2(2): 91-114.

Reid, D.A. (1955). New or interesting records of Australian basidiomycetes: I. Kew Bulletin 10: 637-638.

Ryvarden, L. (2004). Neotropical Polypores. Synopsis Fungorum (Oslo) 19: 81-83.

Sharma, J.R. (2012). Aphyllophorales of Himalaya.BSI Publication, Kolkata, 590pp.

Sorbhoy, A.K., J.L. Varshney \& D.K. Agarwal (1996). Fungi of India (1982-92). CBS Publishers \&Distributors, New Delhi, India, 530pp.

Tiwari, C.K., J. Parihar, R.K. Verma \& U. Prakasham (2013). Atlas of Wood Decaying Fungi of Central India. Tropical Forest Research Institute, Jabalpur, MP, 166pp.

Zhao, C.L. \& B.K. Cui (2012). Three species of Perenniporia (Polyporales) new to China. Mycosystema 31(5): 789-794. 


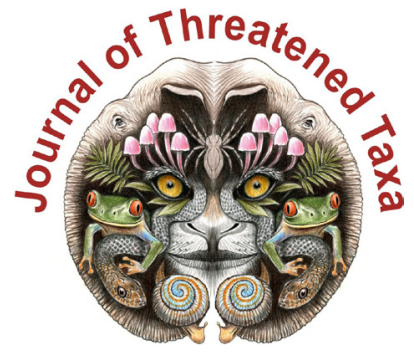

OPEN ACCESS

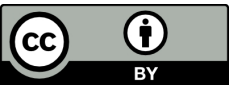

All articles published in the Journal of Threatened Taxa are registered under Creative Commons Attribution 4.0 International License unless otherwise mentioned. JoTT allows unrestricted use of articles in any medium, reproduction and distribution by providing adequate credit to the authors and the source of publication.

\section{ISSN $0974-7907$ (Online); ISSN $0974-7893$ (Print) \\ February 2016 | Vol. 8 | No. 2 | Pages: 8421-8540 \\ Date of Publication: 26 February 2016 (Online \& Print) \\ DOI: 10.11609/jott.2016.8.2.8421-8540 \\ www.threatenedtaxa.org}

Article

Rediscovery, systematics and proposed Red List status of Ledebouria junnarensis S.S. Rahangdale and S.R. Rahangdale nom. nov. (Asparagaceae) - an endemic species from the Western Ghats, Maharashtra, India

-- Savita Sanjaykumar Rahangdale \& Sanjaykumar Ramlal Rahangdale, Pp. 8421-8433

\section{Communications}

Population studies of Lowe's Monkey (Mammalia: Primates: Cercopithecidae: Cercopithecus lowei Thomas, 1923) in Kakum Conservation Area, Ghana

-- Edward D. Wiafe, Pp. 8434-8442

Numerical taxonomy of Berlinia species (Caesalpinioideae: Leguminosae) and their distribution in Nigeria

-- Emmanuel C. Chukwuma, Abiodun E. Ayodele, Michael O. Soladoye \& Deborah M. Chukwuma, Pp. 8443-8451

\section{Data Paper}

Flora of Fergusson College campus, Pune, India: monitoring changes over half a century

-- Ashish N. Nerlekar, Sairandhri A. Lapalikar, Akshay A. Onkar, S.L. Laware \& M.C. Mahajan, Pp. 8452-8487

\section{Short Communications}

Tangled skeins: a first report of non-captive mating behavior in the Southeast Asian Paradise Flying Snake (Reptilia: Squamata: Colubridae: Chrysopelea paradisi)

-- Hinrich Kaiser, Johnny Lim, Heike Worth \& Mark O'Shea, Pp. 8488-8494

Estimating the density of Red Junglefowl Gallus gallus (Galliformes: Phasianidae) in the tropical forest of Similipal Tiger Reserve, eastern India

-- Himanshu S. Palei, Hemanta K. Sahu \& Anup K. Nayak, Pp. 8495-8498
The effect of daytime rain on the Indian Flying Fox (Mammalia: Chiroptera: Pteropodidae Pteropus giganteus) -- S. Baskaran, A. Rathinakumar, J. Maruthupandian, P. Kaliraj \& G. Marimuthu, Pp. 8499-8502

An observation on the Odonata fauna of the AsansolDurgapur Industrial Area, Burdwan, West Bengal, India -- Amar Kumar Nayak \& Utpal Singha Roy, Pp. 8503-8517

Three interesting wood rotting macro-fungi from Jharkhand, India

-- Manoj Emanuel Hembrom, Arvind Parihar \& Kanad Das, Pp. 8518-8525

Notes

Description of a new species of Oligosita Walker (Hymenoptera: Trichogrammatidae) from Punjab, India -- Mohsin Ikram \& Mohd. Yousuf, Pp. 8526-8527

Range extension of Lestes nodalis Selys, 1891 (Odonata: Zygoptera: Lestidae) in southern India

-- K.G. Emiliyamma \& Muhamed Jafer Palot, Pp. 8528-8530

Report on the genus Herdonia Walker (Lepidoptera: Thyrididae) in Karnataka Western Ghats, India -- P.R. Shashank, Pp. 8531-8532

Long-horned grasshoppers (Orthoptera: Tettigoniidae) in Radhanagari Wildlife Sanctuary, Maharashtra, India -- Sunil M. Gaikwad, Yogesh J. Koli, Gopal. A. Raut, Sadashiv H. Waghmare \& Ganesh P. Bhawane, 5pp Pp. 8533-8537

Intrusion of devil weed Chromolaena odorata, an exotic invasive, into Kinnerasani and Eturnagaram wildlife sanctuaries, Telangana, India

-- Sateesh Suthari, Ramesh Kandagatla, Sarede Geetha, Ajmeera Ragan \& Vatsavaya S. Raju, Pp. 8538-8540
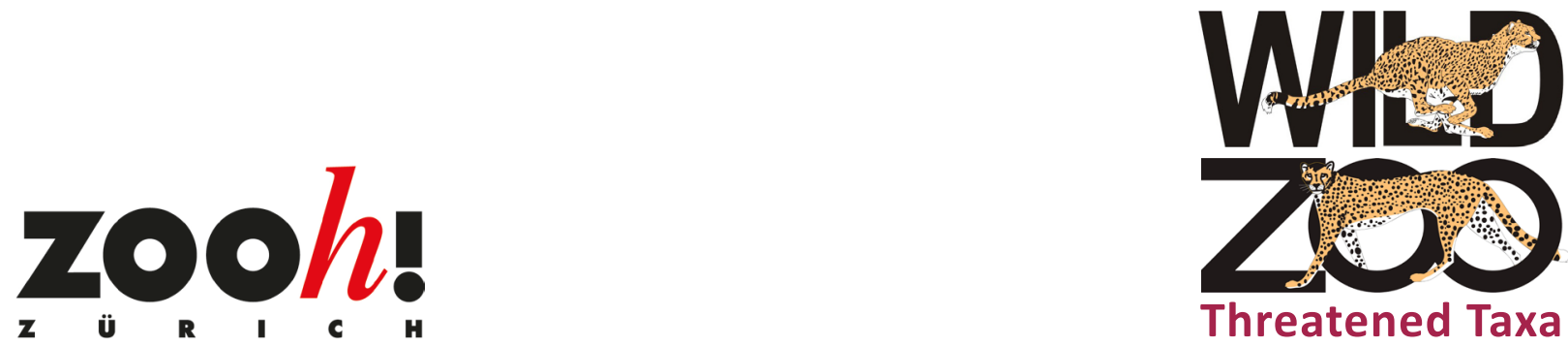